\title{
Failure of intraventricular gammaglobulin and $\alpha$ interferon for persistent encephalitis in congenital hypogammaglobulinaemia
}

\author{
D M ROBERTON, ${ }^{*} \ddagger$ I JACK, $†$ W JOSHI, $\ddagger$ F LAW \\ Departments of ${ }^{*}$ Immunology, †Microbiology, and $¥$ General Paediatrics, Royal Children’s Hospital, \\ Melbourne, Victoria, Australia
}

SUMMARY A boy with congenital hypogammaglobulinaemia died at the age of 12 years after a viral meningoencephalitis of two and a half years duration due to an untypable picornavirus. He had received intravenous immunoglobulin every four weeks from the time of the start of immunoglobulin replacement treatment at the age of 3 years. The encephalitis did not respond to high dose intravenous gammaglobulin ( $2500 \mathrm{~g}$ during 22 months). The virus could not be isolated during the administration of intraventricular immunoglobulin $(38.15 \mathrm{~g})$ and intraventricular recombinant $\alpha$ interferon $\left(121 \times 10^{6}\right.$ units $)$, but recurred rapidly each time intraventricular treatment was stopped. Further modes of treatment are still required for prevention and treatment of this disorder.

Persisting meningoencephalitis, usually fatal, has been described previously in patients with hypogammaglobulinaemia. This disorder has occurred most often in sex linked agammaglobulinaemia, and has commonly been due to infection with echoviruses. Other enteroviruses cause similar infections in sex linked agammaglobulinaemia, however, and vaccine associated poliomyelitis ${ }^{12}$ and Coxsackie B3 meningoencephalitis ${ }^{3}$ have been described. In contrast, persisting meningoencephalitis is rare in late onset primary hypogammaglobulinaemia, although fatal measles encephalitis has been reported in an adult with this condition, ${ }^{4}$ and one patient with late onset hypogammaglobulinaemia died of meningoencephalitis due to infection with echovirus $11 .{ }^{5}$

Standard intramuscular immunoglobulin replacement treatment has not prevented the development of meningoencephalitis. In the absence of effective antimicrobial agents for viruses belonging to the enterovirus group, treatment has been directed towards administration of specific antibody either systemically or directly into the central nervous system. There have been reports of apparent remission after high dose intravenous immunoglobulin, ${ }^{6}$ infusions of specific antibody containing plasma, ${ }^{7}$ and administration of intraventricular immunoglobulin. ${ }^{8}$

This report describes the use of very high dose intravenous immunoglobulin, intraventricular im- munoglobulin, and intraventricular recombinant $\alpha$ interferon in a boy with congenital hypogammaglobulinaemia who developed a viral meningoencephalitis due to an as yet untyped picornavirus. Although virus could not be isolated from cerebrospinal fluid during intraventricular administration of immunoglobulin and recombinant $\alpha$ interferon alone and in combination, viral shedding recurred rapidly each time intraventricular treatment was stopped and ultimately his infection was fatal.

\section{Case report}

The patient, a boy born in 1974 , had recurrent diarrhoea, several episodes of otitis media associated with an aural discharge, and recurrent lower respiratory tract infections from the age of 6 months. Immunological assessment at 3 years of age showed absent tonsils, hypogammaglobulinaemia (IgA, IgM, and IgE not detectable, IgG $1.55 \mathrm{~g} / \mathrm{l}$ ) and absent peripheral blood $B$ cells as determined by surface membrane immunoglobulin bearing lymphocytes. There were no detectable isohaemagglutinins in his serum (blood group A). Polymorphonuclear cell metabolic function was normal, as were his peripheral blood lymphocyte responses to phytohaemagglutinin, pokeweed mitogen, concanavalin A, and allogeneic cells. Peripheral blood T lymphocyte numbers as determined by sheep red cell rosettes 
were $59 \%$. There was no family history of affected males among maternal relatives.

Treatment with intravenous immunoglobulin was started at the time of diagnosis and he received 4-5 $\mathrm{ml} / \mathrm{kg}$ of a $6 \%$ preparation $(240-300 \mathrm{mg} / \mathrm{kg})(\mathrm{Com}-$ monwealth Serum Laboratories) at intervals of four weeks. He remained in excellent health during the next five years. The median serum IgG concentration immediately before immunoglobulin infusions during his eighth year of life was $2 \cdot 78 \mathrm{~g} / \mathrm{l}$.

At $8^{1 / 2}$ years of age he had an illness during which he had vomiting and occasional headaches for 10 days. At 9 years his mother noted a slight mood change; at $91 / 2$ years he developed horizontal nystagmus. Cerebrospinal fluid was examined and showed a raised protein concentration and a mild leucocytosis. A picornavirus was isolated on culture of the cerebrospinal fluid but was not detected in faeces.

The nystagmus persisted and he developed bilateral sensorineural deafness necessitating the use of hearing aids. Psychometric assessments showed defects in short term auditory memory, a discrepancy between verbal and performance scores by the Wechsler Intelligence Scale for Children, and reduced immediate visual memory. At 10 years of age he developed spontaneous bilateral subdural effusions which were drained.
After viral isolation from the initial sample of cerebrospinal fluid at $91 / 2$ years, he started high dose intravenous immunoglobulin treatment (figure). For 22 months he received $200 \mathrm{ml}$ of intravenous immunoglobulin two times a week $(1 \mathrm{~g} / \mathrm{kg} /$ week $)$. The immunoglobulin used had neutralising antibody activity against $30 \mathrm{TCD}_{50}(30$ times the tissue culture dilution $50 \%$ end point) of the virus ranging from $1: 8$ to $1: 32$. Serum from family members was tested against his viral isolates and his father's serum was shown to have a neutralising titre of 1:32. Plasma was obtained from his father on two occasions by plasmapheresis, and the patient received $100 \mathrm{ml}$ of plasma by intravenous infusion each week for two five week treatment periods. Transfer factor was prepared from his father's lymphocytes and was given weekly in conjunction with the plasma infusions.

Virus was not recovered from lumbar samples of cerebrospinal fluid taken during the six months after initial viral isolation, but was detected again in it three weeks after his last plasma infusion. Serum from 300 blood donors chosen at random was screened for neutralising antibodies to the virus isolated. The 11 donors with titres of $>1: 16$ had plasmapheresis performed. An IgG preparation manufactured from this plasma pool was given into his left lateral cerebral ventricle through a Rickham reservoir. The IgG had neutralising antibody activ-

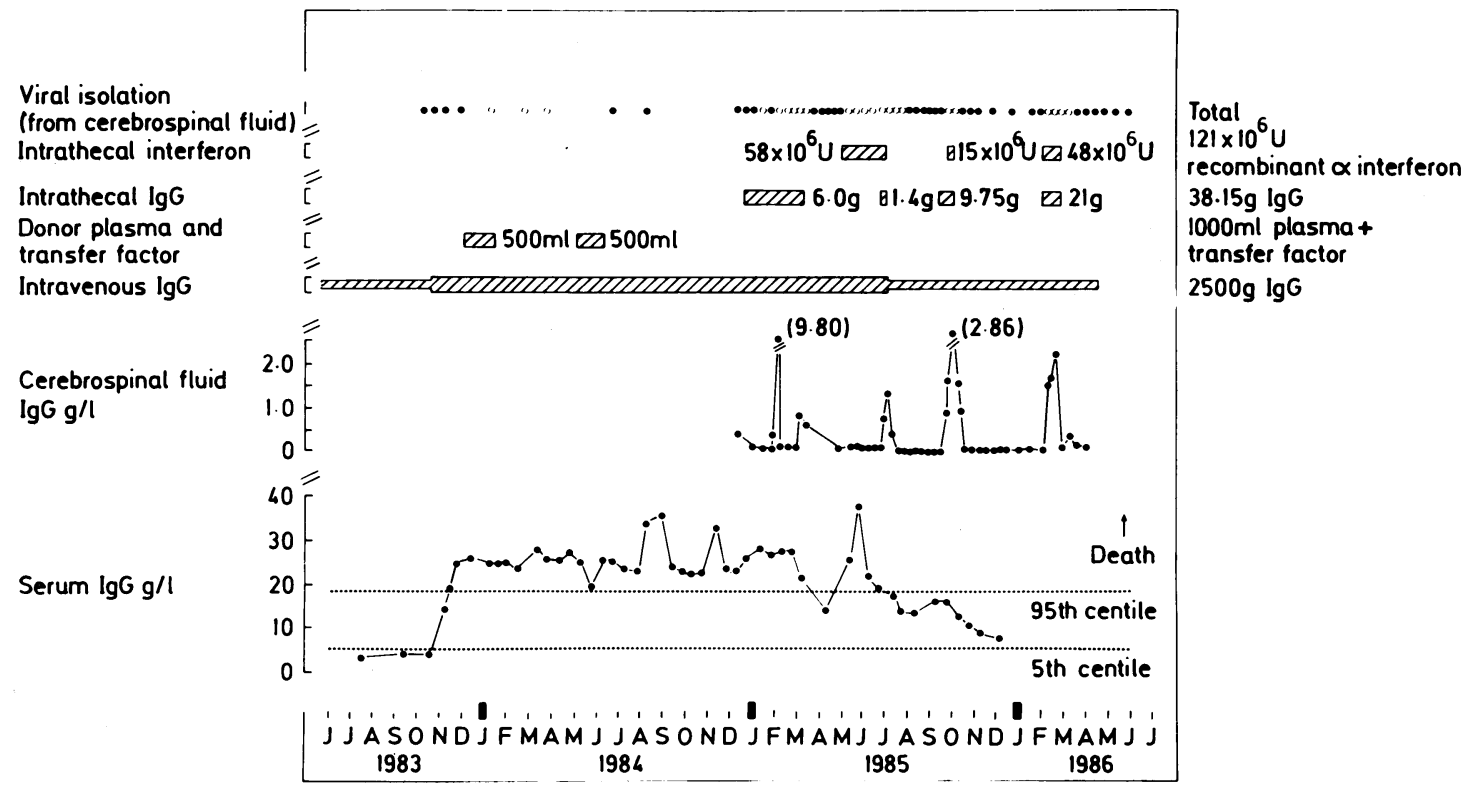

Figure Viral isolation, intrathecal treatment, and serum and cerebrospinal fluid IgG concentrations in the patient over the three years before death. Closed circles represent samples of cerebrospinal fluid from which virus was isolated; open circles represent samples from which virus was not recovered. 
ity against $10 \mathrm{TCD}_{50}$ of the virus of a titre of $>1: 160$, and was given twice weekly for 10 weeks. The total dose administered during the 10 week treatment period was $6 \mathrm{~g}$ of $\mathrm{IgG}$. Virus recovery from ventricular cerebrospinal fluid stopped after four weeks of treatment, but recurred four weeks after stopping the intraventricular treatment.

Recombinant $\alpha$ interferon was donated by Roche Products Proprietary Ltd, and caused a three log reduction in viral plaque formation in in vitro assays using the virus isolated from the patient's cerebrospinal fluid. He initially received $58 \times 10^{6}$ units of recombinant $\alpha$ interferon by the ventricular reservoir. This was given over a 10 week period, with injections being given three times weekly for nine weeks, and daily in conjunction with $240 \mathrm{mg}$ of intraventricular immunoglobulin for six days during the 10th week. Virus was no longer detected in ventricular cerebrospinal fluid after two weeks of treatment but was reisolated two weeks after it was stopped.

Intraventricular Sandoglobulin was then started and was given daily for two weeks; the total dose administered was $9.75 \mathrm{~g}$. During the last five days of this treatment the patient was also given $3 \times 10^{6}$ units of recombinant $\alpha$ interferon daily by the intraventricular route. Virus could not be isolated from the ventricular cerebrospinal fluid 24 hours after the start of treatment but was reisolated two weeks after it was stopped.

Intravenous immunoglobulin administration was decreased to $200 \mathrm{ml}$ weekly in July 1985 at the age of 11 years. He became more lethargic, but continued to attend school. He received further daily intraventricular recombinant $\alpha$ interferon and daily intraventricular Sandoglobulin for three weeks, the total doses administered were $48 \times 10^{6}$ units and $21 \mathrm{~g}$ respectively. Virus isolation stopped within 48 hours of starting treatment but his ventricular cerebrospinal fluid yielded virus again two weeks after treatment was stopped. His nystagmus worsened, he developed a transient hemiparesis and paraesthesiae, became ataxic and lethargic, and then developed urinary retention and faecal incontinence. Convulsions occurred, all active treatment was stopped and he died at the age of 12 years.

\section{Discussion}

The features in this patient of hypogammaglobulinaemia and a slowly progressive meningoencephalitis characterised by sensorineural deafness, deterioration in higher cerebral function, subdural effusions, transient hemiparesis and paraesthesiae, and convulsions are similar to those described by others. Most such patients have been shown to be infected with echoviruses of varying serotypes, although viral isolation has been difficult in some patients. The patient reported here did not have an associated dermatomyositis like illness.

The virus isolated from his cerebrospinal fluid was characterised as a picornavirus on the basis of its appearance on electron microscopy, resistance to ether, and the nature of the cytopathic effect on primary monkey kidney cells and in diploid human fibroblasts. An unusual feature was its inability to grow in HeLa cells. The virus, however, was not able to be typed as being one of the common echovirus strains. Even at low infective doses of 10 to $30 \mathrm{TCD}_{50}$ the virus was not neutralised by antisera to all common echoviruses, to Coxsackie B1-B6 or to polioviruses. Antisera to Coxsackie A viruses were not available but the inability to grow first passage virus in suckling mice suggest it is unlikely that the virus belongs to this group.

Growth of the virus in continuous monkey kidney cells of the MA-104 line produced two discrete plaque sizes of 1-2 $\mathrm{mm}$ and 5-6 mm. Sublines of virus from representative plaque isolates were tested with the above antisera but no neutralisation occurred. Rabbit antisera raised to each of the sublines reacted equally well with the heterologous subline, but neither antiserum neutralised stock cultures of available enteroviruses. It is likely that the variations in plaque size represent genetic variation in a single strain rather than the presence of two separate viruses. These points are being investigated further.

Three recent reports have described at least temporary resolution of symptoms, and cessation of viral isolation, after varying routes of administration of relatively high antibody titre immunoglobulin or plasma preparations to infected patients with primary hypogammaglobulinaemia. ${ }^{679}$ Prentice et al have reported an adult male with sex linked hypogammaglobulinaemia and central nervous system infection with echovirus type 3 who improved clinically while receiving second weekly infusions of plasma, the plasma having a neutralising titre against his echovirus of 1:64 and 1:128 when tested on two different occasions. ${ }^{7}$ A further adult patient with $\mathrm{X}$ linked agammaglobulinaemia and echovirus 11 meningoencephalitis had prolonged remission of his disease after treatment with high dose in travenous immunoglobulin. ${ }^{6}$ Viral shedding recurred when the immunoglobulin was stopped. His condition improved with further intravenous immunoglobulin but recurred when the immunoglobulin infusions were extended from three weekly to four weekly intervals. ${ }^{9}$ Remission was achieved by giving $300 \mathrm{mg}$ of immunoglobulin per kilogram every three weeks and was then maintained until the time of reporting two and a half years later. 
Recently Erlendsson et al reported their treatment of a boy with $\mathrm{X}$ linked hypogammaglobulinaemia with meningoencephalitis from whom echovirus type 5 was isolated at the age of 3 years. ${ }^{8} \mathrm{He}$ failed to respond to intravenous immunoglobulin with a titre of antibody to echovirus 5 of $1: 32$ given at weekly intervals, but when $138 \mathrm{mg}$ of immunoglobulin was given directly into his cerebral ventricles over five days the virus could not be cultured for two months. After reappearance of the virus in his cerebrospinal fluid he received a further $5.6 \mathrm{~g}$ of intraventricular immunoglobulin and he has remained well. The same report described a 12 year old girl with echovirus 25 encephalitis treated in similar fashion who had not had virus cultured from her cerebrospinal fluid during the next 16 months.

There have been several reports of unsuccessful treatment with specific antibodies and with intraventricular immunoglobulin. Plasma infusions containing specific antibody have been unsuccessful or only partly successful in at least four patients $\mathbf{s}^{10-13}$; hyperimmune sheep serum with antibody to echovirus 3 failed to eradicate the virus ${ }^{14}$; and intraventricular immunoglobulin treatment was unsuccessful in two patients. ${ }^{5}{ }^{15}$ In one of the patients failing to respond to intraventricular immunoglobulin, the virus was no longer isolated from ventricular fluid after treatment but treatment had no effect on the patient's progressive course. ${ }^{5}$ The second patient received a total of $12.6 \mathrm{~g}$ of Sandoglobulin in two courses of intraventricular treatment, but echovirus 11 continued to be isolated from the cerebrospinal fluid.

The patient described in this report received a total of $38.15 \mathrm{~g}$ of intraventricular immunoglobulin in four courses of treatment, $1 \mathrm{~g}$ being given daily for 21 consecutive days on one occasion. The immunoglobulin administered came from two geographically different donor pools, and on each occasion virus recovery from cerebrospinal fluid stopped during administration but recurred within weeks of stopping the treatment. He had also received $2500 \mathrm{~g}$ of intravenous immunoglobulin during 22 months of treatment, without apparent effect on the clinical course of his meningoencephalitis. Thus even extremely high dose treatment with immunoglobulin preparations may be unsuccessful in this condition.

Exogenous interferon may be expected to be beneficial in chronic viral disorders by limiting cellular viral replication and preventing infection of uninfected cells. In addition, recombinant human leucocyte interferon has been shown to augment natural killer cell activity as well as antibody dependent cellular cytotoxicity and monocyte cytotoxicity. ${ }^{16}{ }^{17}$ Systemically administered inter- feron is prevented by the blood-cerebrospinal fluid barrier from reaching the central nervous system. ${ }^{18}$ Several investigators have given interferon intrathecally to small numbers of patients with neonatal herpes, multiple sclerosis, or intracranial malignancies, either by the lumbar route ${ }^{1920}$ or by an intraventricular reservoir. ${ }^{18}$ Adminstration has in general been well tolerated, although without specific success in the disorders treated. The use of intrathecal interferon in the treatment of meningoencephalitis associated with hypogammaglobulinaemia has not been reported previously.

The patient reported here received a total of $121 \times 10^{6}$ units of recombinant $\alpha$ interferon in three courses. An initial subcutaneous test dose of 5000 units was given without apparent adverse reaction; this was followed by intraventricular test doses of 2500 units, 25000 units, and 250000 units. During the first course of treatment the interferon was increased to $2 \times 10^{6}$ units three times weekly; during the third course he received $3 \times 10^{6}$ units daily into the cerebral ventricles for 16 days. The only side effect noted was progressively increasing drowsiness during each course of treatment, which resolved within one or two days of its completion.

As with the intraventricular immunoglobulin, virus recovery from ventricular cerebrospinal fluid stopped soon after the start of treatment, but recurred within weeks of it stopping. The period of viral eradication was no greater when immunoglobulin and interferon were used in combination than when immunoglobulin was used alone.

The failure of these two forms of treatment in this patient accentuate the need for the development of further antiviral agents effective against the picornavirus group of agents before successful treatment of this type of infection can be assured in patients with hypogammaglobulinaema. Some such agents may become available: benzimidazole derivatives have been shown to inhibit multiplication of picornaviruses ${ }^{21}$ and more recently an arildone derivative, WIN 51711, has been shown to have antipicornavirus activity. ${ }^{22}$ It is possible that such agents may also have a degree of synergy with interferon (D Tyrell, personal communication). In the absence of effective antiviral chemotherapy, hypogammaglobulinaemic patients who do not respond to intraventricular immunoglobulin treatment may deserve consideration as candidates for bone marrow transplantation in an attempt to provide an adequate immune response to the infecting agent.

We are grateful to Commonwealth Serum Laboratories (Parkville, Australia), Sandoz Australia Proprietary Ltd, and Roche Products Proprietary Ltd, for making their products available to us. We also thank Dr K McGrath and the staff of the Red Cross Blood Bank, Melbourne, and Sisters S Wright, J Hall, and H Upton and Drs H 


\section{Roberton, Jack, Joshi, Law, and Hosking}

Zehnworth, CRF Richardson, and A Tucker for their invaluable help.

Treatment of this patient was approved by the Institutional Ethics Committee.

References

' Wyatt HV. Poliomyelitis in hypogammaglobulinemics. $J$ Infect Dis 1973;128:802-6.

2 Wright PF, Hatch MH, Kasselberg AG, Lowry SP, Wadlington WB, Karzon DT. Vaccine-associated poliomyelitis in a child with sex-linked agammaglobulinaemia. J Pediatr 1977;91: 408-12.

${ }^{3}$ Cooper JB, Pratt WR, English BK, Shearer WT. Coxsackie B3 producing fatal meningoencephalitis in a patient with $\mathrm{X}$-linked agammaglobulinemia. Am J Dis Child 1983;137:82-3.

${ }^{4}$ Graham DG, Gordon A, Ashworth B, Yap PL. Immunodeficiency measles encephalitis. J Clin Lab Immunol 1983;10: $117-20$.

5 Hadfield MG, Seidlin M, Houff SA, Adair CF, Markowitz SM, Straus SE. Echovirus meningomyeloencephalitis with administration of intrathecal immunoglobulin. J Neuropathol Exp Neurol 1985;44:520-9.

${ }^{6}$ Mease PJ, Ochs HD, Wedgwood RJ. Successful treatment of echovirus meningoencephalitis and myositis-fasciitis with intravenous immune globulin therapy in a patient with $\mathrm{X}$-linked agammaglobulinemia. $N$ Engl J Med 1981;304:1278-81.

7 Prentice RL, Wade S, Dalgleish AG, et al. Central nervous system echovirus infection in Bruton's X-linked hypogammaglobulinemia. Aust NZ J Med 1985;15:443-5.

${ }^{8}$ Erlendsson K. Swartz T, Dwyer JM. Successful reversal of echovirus encephalitis in X-linked hypogammaglobulinemia by intraventricular administration of immunoglobulin. $N$ Engl $J$ Med 1985:312:351-3.

9 Mease PJ, Ochs HD, Corey L, Dragavon J, Wedgwood RJ. Echovirus encephalitis/myositis in X-linked agammaglobulinemia. $N$ Engl J Med 1985;313:758.

10 Bardelas JA, Winkelstein JA, Seto DSY, Tsai T, Rogol AD. Fetal ECHO 24 infection in a patient with hypogammaglobulinemia: relationship to a dermatomyositis-like syndrome. J Pediatr 1977;90:396-9.

11 Wilfert CM, Buckley RH, Mohanakumar T, et al. Persistent and fatal central-nervous-system echovirus infections in patients with agammaglobulinemia. $N$ Engl J Med 1977;296:1485-9.
12 Webster ADB, Tripp JH, Hayward AR, et al. Echovirus encephalitis and myositis in primary immunoglobulin deficiency. Arch Dis Child 1978;53:33-7.

13 Weiner LS, Howell JT, Langford MP, et al. Effect of specific antibodies on chronic echovirus type 5 encephalitis in a patient with hypogammaglobulinemia. J Infect Dis 1979;140:858-63.

14 Asherson GL, Webster ADB. Sex-linked hypogammaglobulinaemia. Diagnosis and treatment of immunodeficiency diseases. Oxford: Blackwell, 1980:7-36.

15 Johnson PR, Edwards KM, Wright PF. Failure of intraventricular gamma globulin to eradicate echovirus encephalitis in a patient with X-linked agammaglobulinemia. $N$ Engl J Med 1985;313:1546-7.

${ }^{16}$ Herberman RB, Ortaldo JR, Mantovari A, Hobbs DS, Kung H$F$, Pestka S. Effect of human recombinant interferon on cytotoxic activity of natural killer (NK) cells and monocytes. Cell Immunol 1982;67:160-7.

${ }^{17}$ Ortaldo JR, Mantovani A, Hobbs D, Rubinstein M, Pestka S, Herberman RB. Effects of several species of human leucocyte interferon on cytotoxic activity of NK cells and monocytes. Int $J$ Cancer 1983;31:285-9.

${ }^{18}$ Salazar AM, Gibbs CJ, Gajdusek DC, Smith RA. Clinical use of interferons: central nervous system disorders. In: Came PE, Carter WA, eds. Handbook of experimental pharmacology. Vol 71. Berlin: Springer-Verlag, 1984:471-97.

${ }^{19}$ DeClercq E, Edy VG, De Vlieger H, Eeckels R, Desmyter J. Intrathecal administration of interferon in neonatal herpes J Pediatr 1975;86:736-9.

20) Jacobs L, O'Malley J, Freeman JH, Ekes R. Intrathecal interferon reduces exacerbations of multiple sclerosis. Science 1981;214:1026-8.

${ }^{21}$ DeLong DC, Reed SE. Inhibition of rhinovirus replication in organ culture by a potential antiviral drug. $J$ Infect $D$ is 1980;141:87-91.

22 Otto MJ, Fox MP, Fancher MJ, Kuhrt MF, Diana GD, McKinlay MA. In vitro activity of WIN 51711, a new broadspectrum antipicornavirus drug. Antimicrob Agents Chemother $1985 ; 27: 883-6$.

Correspondence to Dr DM Roberton, Department of Immunology, Royal Children's Hospital, Flemington Road, Melbourne, Victoria, Australia.

Accepted 8 March 1988 